\title{
Jogos virtuais e entretenimento
}

DOI: dx.doi.org/10.18616/nrm07

Jacks Soratto

Ana Cláudia Búrigo Lima

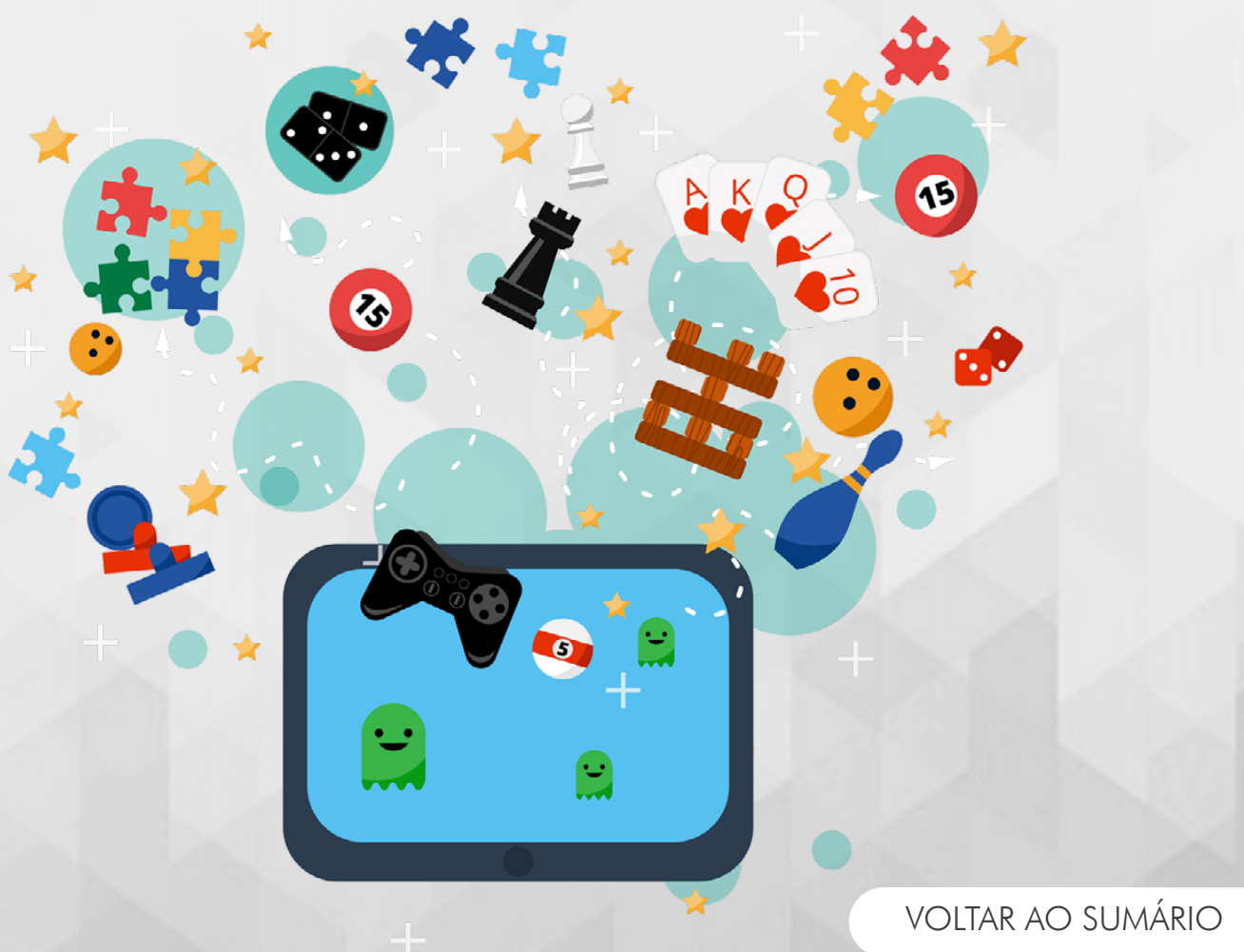


Uma das alternativas para os períodos de diminuição do convívio social é a utilização de jogos virtuais para aprendizagem e entretenimento individual ou coletivo. Os jogos virtuais podem possibilitar o desenvolvimento de habilidades cognitivas, exercitando a perseverança em busca do seu resultado, independentemente dos desafios.

Acesse a loja virtual de seu smartphone ou da empresa (APPLE; SAMSUNG, GOOGLE, 2020) para ter acesso aos seguintes aplicativos:

\section{Formar Palavras - Alfabetização}

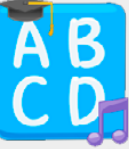

Objetivo: estimular o exercício de palavras relacionadas aos animais, à natureza, aos objetos e às comidas.

\section{Instalar Android}

\section{Instalar IOS}

\section{Peak - jogos para o cérebro}

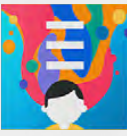

Objetivo: melhorar as habilidades de memória, o foco, a agilidade mental e a linguagem do usuário.

\section{Instalar Android}

\section{Instalar IOS}

\section{Livro de colorir para mim}

Objetivo: estimular a criatividade, a atenção e reduzir os níveis de estresse.

\section{Instalar Android}

StopotS - jogo de stop

Objetivo: estimular o raciocínio rápido e objetivo por meio do preenchimento de todas as colunas com palavras que começam com a letra da rodada, o mais rápido possível.

\section{Instalar Android}

Instalar IOS

Tetris ou Block Puzzle

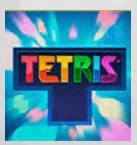

Objetivo: estimular a lógica e o raciocínio por meio do encaixe de peças.

Instalar Android

Instalar IOS 